\title{
Effects of coconut oil on the weight and blood status of grazing cattle fed concentrate as supplementary feed
}

Adelusi, O. O. ${ }^{1}$, Oni, A. O. ${ }^{1}$, Aderinboye, R. Y. ${ }^{1}$, Arigbede, O. M. ${ }^{2}$ and Onwuka, C. F. I. ${ }^{1}$

'Department of Animal Nutrition, ${ }^{2}$ Department of Pasture and Management,

Federal University of Agriculture, Abeokuta, Nigeria

Abstract ${ }^{*}$ Corresponding author: adelusioludotun@ gmail.com. +2348035318400

This study was conducted to determine the effect of coconut oil inclusion on the supplementary feed intake, weight gain, haematology and serum biochemistry of grazing cattle. Twenty-five (25) White Fulani cattle weighing $138 \pm 2.21 \mathrm{~kg}$ were randomly allotted to five treatment groups of coconut oil administration (0 g/day, $50 \mathrm{~g} /$ day, $100 \mathrm{~g} /$ day, $150 \mathrm{~g} /$ day and $200 \mathrm{~g} /$ day) in a completely randomised design. The animals were grazed for 84 days and supplemented with concentrate throughout the experimental period. Data on feed intake, weight gain and blood profile of cattle were analysed using one-way analysis of variance. Results obtained showed that coconut oil did not affect $(P>0.05)$ the supplementary concentrate intake of grazing cattle. Lower $(P<0.05)$ weight gain was observed with animals fed coconut oil at $50 \mathrm{~g} /$ day $(9.64 \mathrm{~kg}$ ) but increased to $17.64 \mathrm{~kg}$ with $150 \mathrm{~g} /$ day. Packed cell volume, haemoglobin and white blood cells were not affected $(P>0.05)$ by coconut oil. The highest $(P<0.05)$ red blood cell $\left(6.91 \times 10^{12} / L\right)$ and platelet counts $\left(67.00 \times 10^{9} / L\right)$ were recorded at $150 \mathrm{~g} /$ day coconut oil. Total cholesterol, $H D L$ and $L D L$ values were increased $(P<0.05)$ with increasing levels of coconut oil. Values obtained for HDL $(166.00 \mathrm{mg} / \mathrm{dL}$ to $145.15 \mathrm{mg} / \mathrm{dL})$ and $L D L(135.00 \mathrm{mg} / \mathrm{dL}$ to $88.40 \mathrm{mg} / \mathrm{dL})$ decreased when the level of oil was increased from 150g/day to 200g/day. Administering coconut oil up to $150 \mathrm{~g} /$ day is recommended as it increases the body weight gain of cattle and maintain the normal PCV and haemoglobin concentration of the animals.

Keywords: Coconut oil, cattle, haematology, serum, weight.

\section{Introduction}

The excretion of methane from the rumen can represent a loss of up to $15 \%$ of the digestible energy, depending on the type of diet and enteric methane which contributes approximately $30-40 \%$ of the total methane produced as greenhouse gas from agricultural sources (Moss et al., 2000). Methane emissions from agriculture represent around $40 \%$ of the emissions produced by human related activities and it is the largest potential contributor to the global warming phenomenon (Moss et al., 2000).

Nutritional strategies identified for reducing methane production include provision of feed additives (chemicals, organic acids, probiotics) and oils in diets, feeding diets rich in unsaturated fatty acids, and modifying feeding practices and supplementing roughage-based diets with deficient nutrients (Sharma, 2005). Coconut oil is highly rated for methane abatement experiments because of its richness in medium-chain fatty acids and has been found to induce significant reductions in methanogenesis (Machmüller and Kreuzer, 1999). However, the extent of the reduction varies from $13-73 \%$, depending on the inclusion level, diet and ruminant species used (Dohme et al., 2000). Boadi et al. (2004) reported that methane mitigation strategies that has no potential negative effects on livestock production hold a greater chance of being adopted, making it necessary to assess the health impact of coconut oil on cattle.

Haematological and biochemical indices of animals may give some insight as to the production performance potentials of 
animals (Orheruata and Akhuomobhogbe, 2006). Several factors such as nutrition, breed, sex, age, reproductive status, environmental factors, stress and transportation were highlighted by Balkei et al. (2007) to affect haematological and biochemical parameters of animals. These factors have played major roles in the differences in haematological and biochemical parameters of animals (Opara and Fagbemi, 2008). Serum creatinine helps in evaluating the liver function and diseases while serum urea evaluates renal function and it may also indicate dehydration (Belewu and Ogunsola, 2010). A lot of studies have been carried out on the feeding values of coconut oil in animal diets and as a methane mitigation strategy. However, little or no work has been reported on the haematological and biochemical parameters of cattle receiving coconut oil at various levels. The present study was therefore, designed to determine the effects of various levels of coconut oil on the supplementary concentrate intake, weight, haematological and serum biochemical parameters of grazing cattle.

\section{Materials and methods}

The experiment was carried out at the Cattle Production Venture Farm, Federal University of Agriculture, Abeokuta, Ogun State, Nigeria. The site is located in the rain forest vegetation zone of South-Western Nigeria on Latitude $7^{\circ} 1358.19 \mathrm{~N}$, longitude $3^{\circ} 2510.36$ Eand an elevation of
$145 \mathrm{~m}$ above the sea level (Google Earth, 2017). The climate is humid with a mean annual rainfall of $1,037 \mathrm{~mm}$ and mean temperature and relative humidity of $34.70 \mathrm{C}$ and $83 \%$ respectively.

Experimental design and animal management

The experimental design for this trial was a completely randomised design (CRD). The factors are five (5) levels of coconut oil administration (0 g/day, $50 \mathrm{~g} /$ day, 100 $\mathrm{g} /$ day, $150 \mathrm{~g} /$ day and $200 \mathrm{~g} /$ day). Weights of individual test ingredients were measured using a sensitive scale at first and then volume for weight measurements was used for onward daily administration.

The animals for this experiment were sourced from the herd maintained under the Cattle Production Venture scheme of Federal University of Agriculture, Abeokuta. Twenty-five (25) White Fulani cattle with average weight of $138 \pm 2.21 \mathrm{~kg}$ were used for this trial that lasted 84 days. The animals were classified into 5 treatment groups according to the levels of coconut oil that make up each treatment. The animals were drenched daily with coconut oil at 0800 hours and then fed concentrate supplement consisting of maize $(13 \%)$, groundnut cake $(7 \%)$, palm kernel cake (20\%), wheat offal (54\%), oyster shell (4\%) and salt (2\%) prior to being released for grazing at 1030 hours. The determined chemical composition of the concentrate diet is shown in Table 1 below.

Table 1: Chemical composition of supplementary concentrate feed

\begin{tabular}{ll}
\hline Nutrient & Composition $(\mathrm{g} / \mathrm{kg})$ \\
\hline Dry matter & 83.3 \\
Crude protein & 16.9 \\
Ether extract & 5.2 \\
Ash & 4.9 \\
Neutral detergent fibre & 42.3 \\
Acid detergent fibre & 17.3 \\
Acid detergent lignin & 4.9 \\
Calcium & 3.0 \\
Phosphorus & 2.7 \\
\hline
\end{tabular}




\section{Adelusi, Oni, Aderinboye, Arigbede and Onwuka}

Feed intake and weight gain measurements

Intake of supplementary concentrate feed was measured before and after grazing period. Prior to the administration of treatments, body weights of animals were taken with the use of a weigh bridge, to monitor the growth of animals throughout the trial period. During the experimental period, the animals were weighed biweekly to determine weight changes in response to different dietary treatments.

\section{Collection of blood samples}

Ten millilitres of blood sample was collected from jugular vein of each animal using hypodermic needle and syringe before the commencement of the experiment and at the end of the $12^{\text {th }}$ week of the experiment. $5 \mathrm{~mL}$ of blood sample was released into the sample bottles containing ethyl dimethyl tetra acetic acid (EDTA) as anti-coagulant. The bottles were rolled thoroughly to ensure proper mixing of the blood with EDTA to prevent coagulation, refrigerated and analysed within $48 \mathrm{hrs}$. The remaining $5 \mathrm{~mL}$ of blood samples was released into plain bottles without anticoagulant to harvest serum.

\section{Blood analyses}

The packed cell volume was measured for each animal in fresh ethylene diamine tetra acetic acid (EDTA) anticoagulant samples within $24 \mathrm{hrs}$ of collection using the microhaematocrit method. Haemoglobin concentration was also measured in fresh EDTA anticoagulant samples using the Sahl's (acid haematin) method (Benjamin, 1978). RBC was measured in fresh EDTA with the aid of Neubaur counting chamber (haemocytometer). Blood smears were used for total thrombocyte, total WBC counts (Tavares-Dias et al., 2008) and WBC differential relative and absolute counts. Differential relative and absolute counts were classified as lymphocytes, neutrophils, eosinophils, basophils and monocytes. Plasma glucose was measured in fluoride oxalate anticoagulant blood samples using the enzymatic glucose oxidase method (Bauer et al. 1974). MCH and $\mathrm{MCHC}$ values were calculated from PCV, Hb and RBC values (Jain, 1993). Total serum protein was measured in serum for individual animal using the biuret method. Alanine aminotransferase (ALT) and Aspartate aminotransferase (AST) were analysed spectrophotometrically by using commercially available diagnostic kits (Randox® Test Kits). Serum albumin and globulin were determined using bromocresol purple method of Varly et al. (1980). Serum creatinine was determined using the principle of Jaffe reaction as described by Bonsnes and Taussky (1945).

\section{Statistical analysis}

The data from this experiment were analysed separately using one-way analysis of variance option of the IBM SPSS Statistics software (Version 20; IBM SPSS 2011). Treatment means were statistically compared using Duncan's Multiple Range Test to identify differences between means and significant differences were declared at $P<0.05$.

Results

The effect of coconut oil on the weight and supplementary feed intake of cattle are presented in Table 2. No significant $(P$ $>0.05$ ) differences were obtained for the final weights and concentrate feed intake of cattle. Animals in the groups that received coconut oil recorded significantly $(P<0.05)$ lower average weight gain, $9.82 \mathrm{~kg}$ for those on $50 \mathrm{~g} /$ day compared to those in the control group (no oil) which recorded 24.67 $\mathrm{kg}$ increase in weight. It was however, observed that weight gain increased with increasing levels of coconut oil. 
Effects of coconut oil on the weight and blood status of grazing cattle fed concentrate as supplementary feed

Table 2: Weight and concentrate intake parameters of cattle drenched various coconut oil levels

\begin{tabular}{llllllll}
\hline & \multicolumn{7}{c}{ Coconut Oil Levels } \\
Parameters & 0g/day & $50 \mathrm{~g} /$ day & $100 \mathrm{~g} /$ day & $150 \mathrm{~g} /$ day & $200 \mathrm{~g} /$ day & SEM & Prob. \\
\hline Initial weight $(\mathrm{kg})$ & 137.00 & 141.00 & 138.00 & 138.00 & 137.33 & 2.211 & 0.91 \\
Final weight $(\mathrm{kg})$ & 161.67 & 150.82 & 151.31 & 155.64 & 154.33 & 2.387 & 0.60 \\
Weight gain $(\mathrm{kg})$ & $24.67^{\mathrm{a}}$ & $9.82^{\mathrm{c}}$ & $13.31^{\mathrm{bc}}$ & $17.64^{\mathrm{b}}$ & $17.00^{\mathrm{b}}$ & 1.558 & 0.01 \\
Weight gain $(\mathrm{g} /$ day) & $293.69^{\mathrm{a}}$ & $116.90^{\mathrm{c}}$ & $158.45^{\mathrm{bc}}$ & $210.00^{\mathrm{b}}$ & $202.38^{\mathrm{b}}$ & 26.417 & 0.00 \\
Concentrate intake (kg/day) & 1.65 & 1.34 & 1.57 & 1.28 & 1.52 & 0.201 & 0.48 \\
\hline
\end{tabular}

${ }^{\text {ab }}$ Means on the same row with the different superscripts are significantly different $(\mathbf{P}<0.05)$

Table 3 showed the effect of coconut oil on haematological values of cattle. Coconut oil did not affect PCV, haemoglobin and MCHC of cattle. Red blood cells and platelets count increased $(P<0.05)$ with increasing levels of coconut oil up to 150 g/day recording $6.91 \times 10^{12}$ and $67.00 \times 10^{2} \mathrm{~L}$ respectively, while a reduction in the values was observed with animals that received $200 \mathrm{~g} /$ day.

Table 3: Haematological values of grazing cattle drenched with varying levels of coconut oil

\begin{tabular}{lllllllll}
\hline & \multicolumn{7}{c}{ Levels of Coconut Oil } \\
Parameters & $\mathrm{NR}^{*}$ & $0 \mathrm{~g} / \mathrm{day}$ & $50 \mathrm{~g} / \mathrm{day}$ & $100 \mathrm{~g} /$ day & $150 \mathrm{~g} /$ day & $200 \mathrm{~g} /$ day & SEM & Prob. \\
\hline Packed cell volume $(\%)$ & $24-46$ & 29.53 & 29.00 & 30.00 & 33.00 & 32.50 & 0.618 & 0.63 \\
Haemoglobin $(\mathrm{g} / \mathrm{dL})$ & $8-15$ & 9.89 & 9.65 & 10.05 & 10.95 & 10.85 & 0.207 & 0.18 \\
Red blood cells $\left(\times 10^{12} / \mathrm{L}\right)$ & $5-10$ & $6.22^{\mathrm{ab}}$ & $6.03^{\mathrm{b}}$ & $6.22^{\mathrm{ab}}$ & $6.91^{\mathrm{a}}$ & $6.85^{\mathrm{a}}$ & 0.130 & 0.02 \\
Platelets $\left(\times 10^{9} / \mathrm{L}\right)$ & $100-800$ & $51.42^{\mathrm{b}}$ & $58.50^{\mathrm{ab}}$ & $58.00^{\mathrm{ab}}$ & $67.00^{\mathrm{a}}$ & $56.50^{\mathrm{ab}}$ & 2.053 & 0.03 \\
MCH $(\mathrm{pg})$ & $11-17$ & $15.91^{\mathrm{ab}}$ & $16.01^{\mathrm{ab}}$ & $16.14^{\mathrm{a}}$ & $15.85^{\mathrm{b}}$ & $15.82^{\mathrm{b}}$ & 0.045 & 0.04 \\
MCHC $(\mathrm{g} / \mathrm{dL})$ & $30-36$ & 33.43 & 33.28 & 33.49 & 33.19 & 33.38 & 0.044 & 0.50 \\
MCV (fl) & $40-60$ & $47.59^{\mathrm{ab}}$ & $48.10^{\mathrm{ab}}$ & $48.20^{\mathrm{a}}$ & $47.75^{\mathrm{ab}}$ & $47.40^{\mathrm{b}}$ & 0.118 & 0.03 \\
\hline *NR: Normal range (Mercks, 2015) & & & & & & & &
\end{tabular}

MCH: Mean cell haemoglobin MCHC: Mean corpuscular haemoglobin concentration

MCV: Mean cell volume

Table 4 showed white blood cells and its percentage differentials of cattle drenched with coconut oil at different levels. There was significant difference $(P<0.05)$ in neutrophils with cattle drenched $100 \mathrm{~g} /$ day oil recording the highest value of $57 \%$. Lymphocyte levels of cattle did not follow particular pattern. However, the highest $(P$ $<0.05)$ value was recorded in animals that received $200 \mathrm{~g} /$ day oil with $65.50 \%$.

Table 4: White blood cell differential count of cattle drenched various levels of coconut oil

\begin{tabular}{lllllllll}
\hline & \multicolumn{7}{c}{ Levels of Coconut Oil inclusion } \\
Parameters & $\mathrm{NR}^{*}$ & $0 \mathrm{~g} / \mathrm{day}$ & $50 \mathrm{~g} / \mathrm{day}$ & $100 \mathrm{~g} /$ day & $150 \mathrm{~g} / \mathrm{day}$ & $200 \mathrm{~g} /$ day & $\mathrm{SEM}$ & Prob. \\
\hline White blood cells $\left(\times 10^{9} / \mathrm{L}\right)$ & $4-12$ & 9.23 & 9.65 & 12.85 & 8.55 & 10.15 & 0.794 & 0.79 \\
Neutrophils $(\%)$ & $15-33$ & $40.25^{\mathrm{b}}$ & $37.00^{\mathrm{b}}$ & $57.00^{\mathrm{a}}$ & $38.50^{\mathrm{b}}$ & $30.00^{\mathrm{c}}$ & 2.426 & 0.00 \\
Lymphocytes $(\%)$ & $62-63$ & $56.91^{\mathrm{b}}$ & $59.50^{\mathrm{b}}$ & $40.00^{\mathrm{c}}$ & $58.50^{\mathrm{b}}$ & $65.50^{\mathrm{a}}$ & 2.319 & 0.00 \\
Eosinophils (\%) & $0-20$ & 2.42 & 2.50 & 2.00 & 2.50 & 3.00 & 0.155 & 0.31 \\
Monocytes (\%) & $0-8$ & 0.42 & 1.00 & 1.00 & 0.50 & 1.50 & 0.167 & 0.16 \\
Basophils (\%) & $0-2$ & 0.00 & 0.00 & 0.00 & 0.00 & 0.00 & 0.000 & 0.00 \\
\hline ab Means on the same row with the different superscripts are significantly different $(\mathbf{P}<\mathbf{0 . 0 5})$
\end{tabular}

*NR: Normal range (Mercks, 2015)

Table 5 showed the blood serum biochemistry of grazing cattle drenched with various levels of coconut oil. Blood glucose and total bilirubin contents of cattle were not significantly affected $(P<0.05)$ by coconut oil inclusion. However, there was significant difference $(P<0.05)$ in blood urea nitrogen, creatinine, conjugated bilirubin and total protein content. Animals that received $100 \mathrm{~g}$ /day coconut oil had 


\section{Adelusi, Oni, Aderinboye, Arigbede and Onwuka}

lower conjugated bilirubin content $(0.10$ $\mathrm{mg} / \mathrm{dL}$ ) when compared with the animals on the other levels. Total cholesterol, HDL and LDL values were increased $(P<0.05)$ with increasing levels of coconut oil administration. A reduction in the HDL and LDL values were however, observed when the levels of coconut oil increased from 150 g/day to $200 \mathrm{~g} /$ day.

Table 5: Serum biochemistry of grazing cattle drenched with varying levels of coconut oil

\begin{tabular}{|c|c|c|c|c|c|c|c|c|}
\hline \multirow[b]{2}{*}{ Parameters } & \multicolumn{7}{|c|}{ Levels of coconut oil inclusion } & \multirow[b]{2}{*}{ Prob. } \\
\hline & NR* & $0 \mathrm{~g} /$ day & $50 \mathrm{~g} /$ day & $100 \mathrm{~g} /$ day & $150 \mathrm{~g} /$ day & $200 \mathrm{~g} /$ day & SEM & \\
\hline Glucose $(\mathrm{mg} / \mathrm{dL})$ & $40-100$ & 73.22 & 72.00 & 77.00 & 74.50 & 71.50 & 0.898 & 0.88 \\
\hline Blood urea nitrogen $(\mathrm{mg} / \mathrm{dL})$ & $10-25$ & $22.38^{\mathrm{ab}}$ & $25.50^{\mathrm{a}}$ & $19.00^{\mathrm{bc}}$ & $23.00^{\mathrm{ab}}$ & $17.00^{\mathrm{c}}$ & 1.041 & 0.04 \\
\hline Creatinine $(\mathrm{mg} / \mathrm{dL})$ & $0.5-2.2$ & $0.70^{\mathrm{b}}$ & $0.80^{\mathrm{ab}}$ & $0.85^{\mathrm{a}}$ & $0.80^{\mathrm{ab}}$ & $0.85^{\mathrm{a}}$ & 0.019 & 0.01 \\
\hline Total bilirubin (mg/dL) & $0-1.6$ & 0.80 & 0.70 & 0.70 & 0.70 & 0.75 & 0.021 & 0.53 \\
\hline Conjugated bilirubin $(\mathrm{mg} / \mathrm{dL})$ & $0.1-0.4$ & $0.24^{\mathrm{a}}$ & $0.20^{\mathrm{a}}$ & $0.10^{\mathrm{b}}$ & $0.25^{\mathrm{a}}$ & $0.20^{\mathrm{a}}$ & 0.018 & 0.04 \\
\hline Total protein $(\mathrm{g} / \mathrm{dL})$ & $6.7-7.5$ & $8.85^{\mathrm{a}}$ & $7.40^{\mathrm{d}}$ & $8.60^{\mathrm{ab}}$ & $8.15^{\mathrm{bc}}$ & $7.60^{\mathrm{cd}}$ & 0.165 & 0.01 \\
\hline Total Cholesterol (mg/dL) & - & $188.64^{\mathrm{c}}$ & $197.75^{\mathrm{c}}$ & $259.25^{\text {ab }}$ & $226.55^{\mathrm{bc}}$ & $304.65^{\mathrm{a}}$ & 12.631 & 0.00 \\
\hline $\mathrm{HDL}(\mathrm{mg} / \mathrm{dL})$ & - & $121.42^{\mathrm{b}}$ & $120.60^{\mathrm{b}}$ & $128.65^{\mathrm{ab}}$ & $166.00^{\mathrm{a}}$ & $145.15^{\text {ab }}$ & 6.758 & 0.05 \\
\hline $\mathrm{LDL}(\mathrm{mg} / \mathrm{dL})$ & - & $69.24^{\mathrm{b}}$ & $69.05^{\mathrm{b}}$ & $127.95^{\mathrm{a}}$ & $135.00^{\mathrm{a}}$ & $88.40^{\mathrm{b}}$ & 8.763 & 0.021 \\
\hline
\end{tabular}

\section{Discussion}

A decrease in dry matter intake from the inclusion of coconut oil has been widely reported (Machmüller and Kreuzer, 1999; Lovett et al., 2003). However, no difference in intake was observed in cattle that were drenched with coconut oil at various levels in this experiment. This level of intake can be as a result of the effect of oil on rumen micro-organisms as noted in the study of Adelusi et al. (2015) where a mixture of coconut and palm kernel oils was reported to have reduced rumen microbial populations. Machmüller and Kreuzer (1999) observed that the addition of $70 \mathrm{~g} / \mathrm{kg}$ of dietary coconut oil reduced intake of lambs. The authors reported that one possible reason for this finding could be reduced palatability and because of the depression in feed intake. Sutton et al. (1983) suggested that the maximum coconut oil in sheep diet should be limited to $40 \mathrm{~g} / \mathrm{d}$ per animal. The performance of cattle in terms of body weight gain decreased as the administration of coconut oil increased from 150 to $200 \mathrm{~g} /$ day, a result which was similar to the report of Phengvilaysouk and Wanapat (2008). The authors observed reduced weight changes when buffaloes were fed ad libitum rice straw supplemented with coconut oil at 2 $\mathrm{mL} / \mathrm{kg}$ body weight but observed improved live weight changes when cassava hay was added. All the cattle drenched with coconut oil in this study were able to maintain body weight over the course of the experiment when compared with the control. The result in this study was similar to the report of Bhatt et al. (2011) that obtained comparable average daily gain in lambs maintained on control and coconut oil supplemented groups. The authors adduced similarity in weight changes to have been due to similar fibre digestibility in all the groups.

Packed cell volume (PCV) is the volume of erythrocytes expressed as a percentage of the volume of whole blood in a sample. It is the most accurate means of determining red blood cell volume and can be used to deduce total blood volume and haemoglobin levels. Several factors affect PCV levels (Ndlovu et al. 2007). The implication of these observed PCV values, going by the reports of Ganong (2001) is that all the animals on the various levels of coconut oil inclusion shows the tendency for a return of PCV to normal level following an infection through compensatory accelerated production. The blood haemoglobin of cattle was not 
affected with or without inclusion of coconut oil, and the values were well within the range reported as normal for cattle (Mercks, 2015). With the relatively higher $\mathrm{Hb}$ concentration in cattle that received coconut oil over control in this study, it indicated that dietary treatments generally seemed to be capable of supporting high oxygen carrying capacity of the blood in the cattle. Increased RBC counts obtained for cattle that received coconut oil over control in this study showed that the animals are not susceptible to anaemia-related disease conditions.

The cattle in this study with WBC that is within the recommended range seem to possess a protective system, which provide a rapid and potent defence against any infectious agent. The reason for this is probably because the animals have developed physiological adaptation in their ecological zone (Daramola et al., 2005). Higher levels of lymphocytes values in cattle that received coconut oil over control in this study are suggestive of a welldeveloped immune system in the cattle with such number of immune cells to proffer good health (Daramola et al., 2005). Neutrophils values in cattle drenched with coconut oil in this study decreased from $0 \mathrm{~g} /$ day to $200 \mathrm{~g} /$ day level of inclusion while lymphocytes values were vice versa. The results in this study agreed with the findings of Lazzaro (2001) on increase in neutrophils with a decrease in lymphocytes and vice versa.

The serum glucose concentration of cattle on coconut oil supplementation in this study was within the normal range for healthy ruminants (Blood et al., 1983). In a study reported by Johnson et al. (1988), it was observed that no effects were recorded in glucose concentration when dairy cows were fed with supplementary dietary fat. The blood-urea nitrogen values that increased when coconut oil increased from 0 to $50 \mathrm{~g} /$ day is in agreement with the reports of Phengvilaysouk and Wanapat (2008) which obtained increased blood urea nitrogen when buffaloes were supplemented with cassava hay and coconut oil. However, it was observed that levels of blood urea nitrogen decreased with increased level of coconut oil. The values obtained are also within the 20.3 $\mathrm{mg} / \mathrm{dL}$ range obtained by Wanapat et al. (2005) when dairy cows were fed $4 \%$ coconut oil. The variations in the levels of blood urea nitrogen across the treatments applied in this study can be a reflection of how oil affects protein metabolism as blood urea has been known to be related to inefficient utilization of dietary crude protein in ruminants (Lewis, 1975).

The serum cholesterol profile of cattle in this study increased as the level of coconut oil administered to the animals increased. This finding is in agreement with the study of Khorasani and Kennelly (1998) which reported an increase in serum cholesterol of dairy cows when fed with a concentrate: forage based diet that was supplemented with canola fat levels varying from 37.5 to $75 \mathrm{~g} / \mathrm{kg}$. Bhatt et al. (2011) also reported that the concentration of serum cholesterol and non-esterified fatty acids increased when lambs were supplemented with coconut oil. However, there was a reduction in HDL and LDL values of cattle as the level of coconut oil increased from 150 to 200 $\mathrm{g} /$ day. This reduction was in agreement with Khorasani and Kennelly (1998) that, further increases in the fat level from 110 to $145 \mathrm{~g} / \mathrm{kg}$ in the diet lowered the concentrations of free-fatty acids and serum cholesterol. The linear increase in cholesterol concentration with increasing level of supplementation of coconut oil is in agreement with Bindel et al. (2000). The increase in serum cholesterol might be due to increased fat synthesis as a result of administered coconut oil. Nestel et al. (1978) proposed that an increase in dietary fat could stimulate intestinal synthesis of 
cholesterol in order to meet the increased demand for the absorption and transportation of fat in ruminants.

In conclusion, cattle drenched with coconut oil were able to increase their body weight as the level of coconut oil was increased to $150 \mathrm{~g} /$ day. Inclusion of coconut oil does not have negative effects on PCV and haemoglobin count of cattle. The blood glucose of animals drenched with coconut oil was within the normal range expected of healthy cattle and there was no significant variation in the WBC of cattle that received coconut oil and those in the control group. There was increment in blood cholesterol of cattle drenched with coconut oil up to $150 \mathrm{~g} /$ day. Administering coconut oil up to $150 \mathrm{~g} /$ day increased the body weight gain of cattle and is hereby recommended.

\section{Acknowledgements}

The authors gratefully acknowledge the support of Cattle Production Ventures, Federal University of Agriculture Abeokuta, Nigeria for the provision of animals and facilities to carry out this study.

\section{References}

Adelusi, O. O., Onwuka, C. F. I., Anifowose, I. O., Ojo, V. O. A. and Yusuf, K. O. 2015. Effects of mixtures of coconut and palm kernel oil on the rumen fermentation parameters and microbial population of cattle. Livestock Research for Rural Development. Volume 27, Article \#136. Retrieved May 30, 2016 f r o m http://www.lrrd.org/lrrd27/7/adel27 136.htm

Balikei, E., Yildiz, A. and Gurdogan, F. 2007 . Blood metabolite concentrations during pregnancy and post-partum in Akkaraman ewes. Small Ruminant Research 67:247-251.
Bauer, T. D., Ackermann, P. G. and Toro, G. 1974. Methods in clinical chemistry. Clinical laboratory methods. The CV Mosley Company, Saint Louis. 946.

Belewu, M. A. and Ogunsola, F. O. 2010. Haematological and serum indices of goat fed fungi treated Jatropha curcas kernel cake in a mixed ration. Journal of Agricultural Biotechnology and Sustainable Development, 2(3), 035-038.

Benjamin, M. M. 1978. Outline of Veterinary clinical pathology, 2nd edition. IOWA Press. IOWA, U. S. A. 35-105.

Bhatt, R. S., Soren, N. M., Tripathi, M. K. and Karim, S. A. 2011. Effects of different levels of coconut oil supplementation on performance, digestibility, and rumen fermentation and carcass traits of Malpura lambs. Animal Feed Science and Technology, 164: 29-37.

Bindel, D. J., Drouillard, J. S., Titgemeyer, E. C., Wessels, R. H., Loest, C. A. 2000. Effects of ruminally protected choline and dietary fat on performance and blood metabolites of finishing heifers. Journal of Animal Science, 78, 24972503.

Blood, D. C., Radostis, O. M., Handerson, J. A., Arunded, J. H., Gay, C. C. 1983. Normal laboratory values. In: Veterinary Medicine, 6th ed. ELBS and Baillière, Tindall, Eastbourne, UK.

Boadi, D., Benchaar, C., Chiquette, J. and Massé, D. 2004. Mitigation strategies to reduce enteric methane emissions from dairy cows: Update review. Canadian Journal Animal Science 84: 319-335.

Bonsnes, R. W. and Taussky, H. H. J. 1945. Determination of creatinine in plasma and urine. Journal 
Effects of coconut oil on the weight and blood status of grazing cattle fed concentrate as supplementary feed

Biochemistry 58:581-589.

Daramola, J. O., Adeloye, A. A., Fatoba, T. A. and Soladoye, A. O. 2005. Haematological and biochemical parameters for West African Dwarf goats. Livestock Research for Rural Development, Vol. 17 Article \#8. Retrieved May 30, 2016, from http://www.lrrd.org/lrrd17/8/dara17 095.htm

Dohme, F., Machmüller, A., Wasserfallen, A. and Kreuzer, $M$. 2000. Comparative efficiency of various fats rich in medium-chain fatty acids to suppress ruminal methanogenesis as measured with RUSITEC. Canadian Journal of Animal Science, 80(3): 473-482.

Ganong, F. W. 2001. Review of medical physiology. McGraw Hill, U.S.A.

G o o g l e $\mathrm{e}$ a $\mathbf{r} \mathbf{t} \mathbf{h}, \quad 2 \quad 0 \quad 1 \quad 7$. http://www.google.earth

IBM SPSS, 2011. Statistics Version 20. IBM Corporation.

Jain, N. C. 1993. Essentials of Veterinary Haematology. Lea and ferbeiger, Pennsylvania, U.S.A. 7.

Johnson Jr., J. C., Utley, P. R., Mullinix Jr., B. G., Merrill, A. 1988. Effects of adding fat and lasalocid to diets of dairy cows. Journal of Dairy Science, 71: 2151-2165.

Khorasani, G. R. and Kennelly, J. J. 1998. Effect of added dietary fat on performance, rumen characteristics, and plasma metabolites of mid lactation dairy cows. Journal of Dairy Science, 81: 2459-2468.

Lazzaro, J. 2001. Normal blood chemistry values for adult goats. www.saanendoah. com/ bloodvalues.html.

Lewis, D. 1975. Blood-urea concentration in relation to protein utilization in the ruminant. Journal of Agricultural Science (Camb.) 48: 438.
Lovett, D., Lovell, S., Stack, L., Callan, J., Finlay, M., Conolly, J. and O'Mara, F. P. 2003. Effect of forage/concentrate ratio and dietary coconut oil level on methane output and performance of finishing beef heifers. Livestock Science, 84:135146.

Machmüller, A. and Kreuzer, M. 1999. Methane suppression by coconut oil and associated effects on nutrient and energy balance in sheep. Canadian Journal of Animal Science, 79: 65-72.

Mercks, 2015. Merck Veterinary Manual. http://www.merckmanuals.com/vet/ appendixes

Moss, A. R., Jouany, J. P., Newbold, J. 2000. Methane production by ruminants: its contribution to global warming. Annales de Zootechnie. 49: 231-253.

Ndlovu, T., Chimonyo, M., Okoh, A. I., Muchenje, V., Dzama, K., Raats, J. G. 2007. Assessing the nutritional status of beef cattle: current practices and future prospects. African Journal of Biotechnology, 6 (24), pp. $\begin{array}{llllllllll}2 & 7 & 2 & 7 & - & 2 & 7 & 3 & 4\end{array}$. http://www.academicjournals.org/A $\underline{\mathrm{JB}}$

Nestel, P. J., Poyser, A., Hood, R. L., Mills, S. C., Willis, M. R., Cook, L. J., Scott, T. W. 1978. The effect of dietary fat supplements on cholesterol metabolism in ruminants. Journal of Lipid Research, 19: 899-908.

Opara, M. N. and Fagbemi, B. O. 2008. Haematological and plasma biochemistry of the adult wild African grasscutter (Thryonomys swnderianus): A zoonosis factor in the tropical humid rain forest of Southeast Nigeria. Annals of New York Academy of Science. 1149:394397. 
Orheruata, A. M. and Aikhuomobhogbe, $P$.U. 2006. Haematological and blood biochemical indices of West African Dwarf (WAD) goats vaccinated against pestes de petite ruminant (PPR). African Journal of Biotechnology 5:743-748.

Phengvilaysouk, A. and Wanapat, M., 2008. Effect of coconut oil and cassava hay supplementation on rumen ecology, digestibility and feed intake in swamp buffaloes. Livestock Research for Rural Development. Volume 20, supplement. http://www.lrrd.org/lrrd20/supplem ent/amma2.htm

Sharma, R. K. 2005. Nutritional strategies for reducing methane production by ruminants-a review. SKUASTJournal. 4: 1.

Sutton, J. D., Knight, R., McAllan, A. B. and Smith, R. H. 1983. Digestion and synthesis in the rumen of sheep given diets supplemented with free and protected oils. British Journal of Nutrition, 49: 419-432.
Tavares-Dias, M., Oliveira-Junior, A., Marcon, J. L. 2008. Methodological limitations of counting total leukocytes and thrombocytes in reptiles (Amazon turtle, Podocnemis expansa): An analysis and discussion. Acta Amazonica, 38, 159-163.

Varly, H., Van, E., Kass, I. 1980. Practical clinical Chemistry, New York, Inter Science Publishers Inc. 197-240.

Wanapat, M. Petlum, A. and Chanthai, S. 2005. Effects of levels of urea and coconut oil on rumen ecology, milk yield and composition in lactating dairy cows fed on urea-treated rice straw. Workshop-seminar "Making better use of local feed resources" (Editors: Reg Preston and Brian Ogle) MEKARN-CTU, Cantho, 2325 May, 2005. Article \#13. Retrieved f $r$ o m http://www.mekarn.org/proctu/wan a13.htm

Received: $20^{\text {th }}$ November, 2017

Accepted: $2^{\text {nd }}$ March, 2018 